\title{
Clear cell carcinoma arising in previous episiotomy scar: a case report and review of the literature
}

\author{
Ling Han, Ai Zheng ${ }^{*}$ and He Wang*
}

\begin{abstract}
Background: Malignant transformation of endometriosis associated with episiotomy scar is a rare event, especially histological type of clear cell adenocarcinoma. There are only three clear cell carcinoma in episiotomy scar reported, no standard treatment established.

Case presentation: A 36-year-old woman presented with a two-month history of painless but puritic perineal lump which she noticed was gradually enlarging. She had undergone surgical excision of a mass in the episiotomy scar 9 year ago and resequently histological type of endometriosis. Physical examination revealed a $10 \times 5 \mathrm{~cm}$ soft, purple scar which is closely related to the apex of the episiotomy. We underwent a local excision of the mass for a biopsy. The second surgery performed after one cycle of paclitaxel and cisplatin (TP) to permit clearance of tumor while preserving normal vaginal function.Pathological result was clear cell adenocarcinoma. Two cycles of TP adjuvant chemotherapy were administrated after surgery.
\end{abstract}

Conclusions: We report a case of primary clear cell carcinoma developing within a previous episiotomy scar in a patient with a history of endometriosis, along with a review of the literature. Accumulation of management data on these rare tumors and Long-term follow-up of such patients is therefore important.

Keywords: Endometriosis, Clear cell carcinoma, Episiotomy scar, Malignant transformation

\section{Background}

Malignant transformation of endometriosis associated with episiotomy scar is a rare event, especially histological type of clear cell adenocarcinoma. In 1990 Hitti first described primary clear cell adenocarcinoma in a perineal endometriosis. To the best of our knowledge, there are only three case reports on record. We report a case of primary clear cell Carcinoma developing within a previous episiotomy scar in a patient with a history of endometriosis, along with a review of the literature.

\section{Case presentation}

A 36-year-old woman presented with a two-month history of painless but puritic perineal lump which she noticed was gradually enlarging. The patient's past gynecological history included frequent vaginitis owing to bad health

\footnotetext{
*Correspondence: anjella1234@sina.com; wanghe_cd@126.com Ling Han first author.

Department of Obstetrics and Gynecology, West China Second University Hospital, Chengdu, China
}

habits and the lack of professional treatment. Because of discomfort, the patient often scratched the vulva including the lesion of the episiotomy scar for many years. In addition, her past obstetric history was significant. She had a history of a forceps delivery 20 years ago. The postoperative recovery of perineal wound was slow. Several months after delivery, she experienced cyclic perineal pain and swelling of the episiotomy scar. Mifesterone and Medroxyprogesterone acetate injectable suspension (DMPA) were used and the pain was relieved. She had undergone surgical excision of a mass in the episiotomy scar 9 year ago and resequently histological type of endometriosis. DMPA was administrated for one year and then mifesterone for half a year. Medical treatment with Chinese traditional medicine was prescribed after that.

Physical examination revealed a $10 \times 5 \mathrm{~cm}$ soft, purple scar which is closely related to the apex of the episiotomy. Pelvic examination and trans-vaginal ultrasound did not detect other signs of pelvic or extra-pelvic endometriosis. We underwent a local excision of the mass for a biopsy 
(Fig. 1a and b). Microscopically, pathological result was clear cell adenocarcinoma (Fig. 2c and d). Endometriotic focus was seen at the side of the cacinous area (Fig. 2e). We clearly noticed transitional dysplastic zone between the endometriotic focus and the clear cell carcinoma (Fig. 2f). The second surgery performed after one cycle of paclitaxel and cisplatin (TP) to permit clearance of tumor while preserving normal vaginal function. The patient underwent radical vulvar excision with skin graft and inguinal lymphadenectomy. The pathologic result showed the deep and lateral margins are clear. The patient was discharged after 10 days of hospitalization without any complication. Two cycles of TP adjuvant chemotherapy were administrated after surgery. The patient has returned to work at the time of manuscript preparation.

\section{Discussion}

Sampson first proposed three criteria to diagnosis malignancy arising in endometriosis in 1925 [1]. The clinical symptoms of malignancy of endometriosis were menstrual irregularity, the enlargement of the mass, increased pain, etc. There are no specific tumor markers in malignant transformation of extraovarian lesions. J. Cuisenier reported the level of CA125 is within normal range in $44 \%$ of patients with extraovarian lesions versus just $15.38 \%$ of patients in ovarian endometriosis [2]. Patients with endometriosis were reported to be 3-folds associated with clear cell carcinoma and endometroid carcinoma. Because of the high risk and no typical clinical tumor marker, patients those were verified as endometriosis in episiotomy scar should be followed up closely.

Endometrioid and clear cell carcinomas are a more common histotype in endometriosis associated ovarian carcinoma (EAOC) than in non-EAOC. The histotype of malignancy occurring from extraovarian endometriosis was reported as follows: endometrioid carcinoma between 75.9 and $69.1 \%$, clear cell carcinoma between 13.5 and $4.5 \%$ [3]. Sara C reported 28 cases of malignancy arising from abdominal wall scars, of which 22 were endometroid or clear cell carcinoma [4]. Among four reported malignancies arising from episiotomy scars, three were clear cell carcinoma [3, 5-7]. The presence of a transitional dysplatic zone between benign endometriosis and cancer is one of the most important feature in the microscopic appearance of a carcinoma arising from endometriotic foci [8]. Approximately 36-42\% of endometriosis associated cancers have this dysplatic zone [9]. The previous three cases of clear cell carcinoma arising from episiotomy scar also reported the transitional zone. The transitional zone was detected in our report. In addition, similar to the present case, the microscopic or macroscopic coexistence with endometriosis was reported in the past three cases.

The best explanation of the pathogenesis of endometriosis in episiotomy scar is transport theory. Transport theory involves iatrogenic transplantation of the endometrium to the surgical wound. Our patient had a lateral episiotomy because of dystocia. This theory might explain the endometrial tissue can be transported to the vulvar tissue during delivery. However, this theory can not explain the rare cases of endometriosis in organs such as the lung and kidney [10]. There are other theories such as lymphatic or haematogenic dissemination, coelomic metaplasia and cell immunity change theory, which are proposed to explain this.

Whether or not endometriosis in episiotomy scar is a sign of its progression to carcinoma have a controversy. The rare case of this clear cell carcinoma in previous episiotomy scar may give evidence to tumor carcinogenesis in extraovarian endometriosis. The etiology of malignant transformation of endometriosis is not clear. Several aspects were summarized as the cause of malignant transformation of endometriosis. First, the genetic mutation was proposed to be associated with the transformation of endometriosis into carcinoma. Loss of heterozygosity at locus 10q23.3, mutation of the tumor suppressor gene PTEN and P53 alteration was reported to be relevated with the development of endometriosis

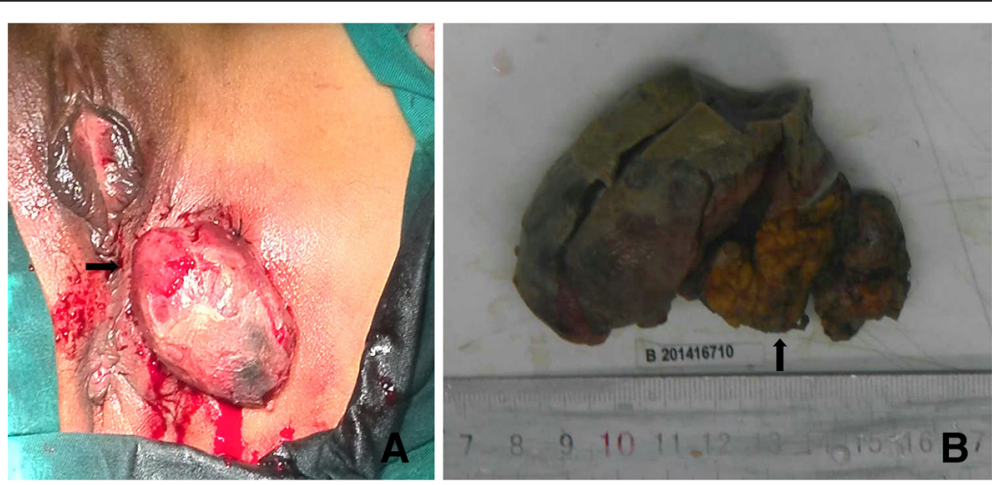

Fig. 1 a Perioperative photograph showing a $10 \times 5 \mathrm{~cm}$ perineal mass arising from the episiotomy scar. b Cut surface of the tumor, pink-yellow in color 

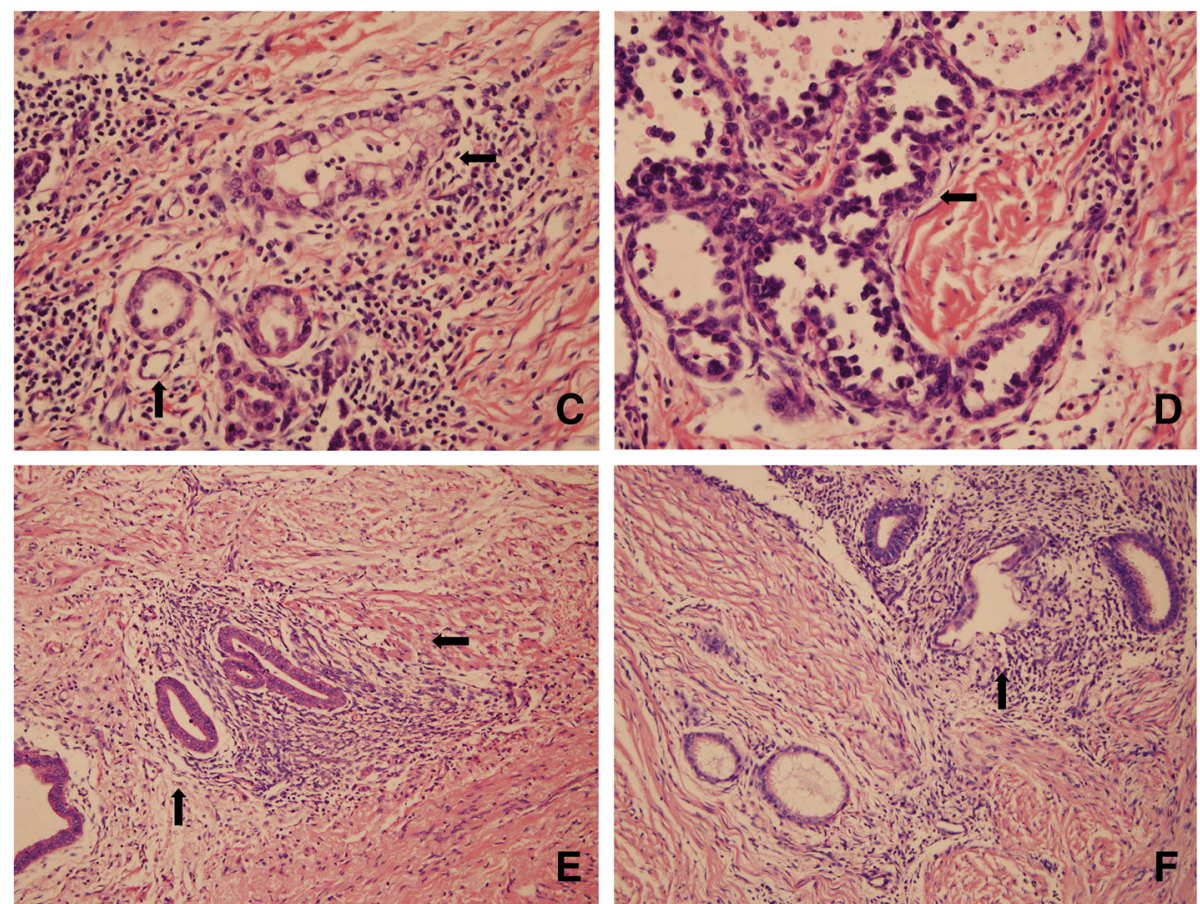

Fig 2 Microscopic images: c clear cell adenocarcinoma: marked cellular pleomorphism, clear cytoplasm, nuclei show pleomorphism. d Characteristic hobnail cells are noted in our case. e Endometriosis: cystic dilated endometrial glands in dense stroma. f Transitional zone revealing clear cell carcinoma arising from the endometriotic focus

associated cancer [11]. Mutations of ARIDIA was reported more often in clear cell carcinoma [12]. David G. Huntsman reported the Mutations of ARIDIA and the loss of BAF250a expression, is an early event in the transformation of endometriosis into cancer [13]. ARID1A inactivation and PI3K/AKT pathway alterations may be consistent to initiate carcinogenesis [14]. The detection of gene mutation is difficult in clinical work, but these research give us some potential therapeutic approach in the future.

Secondly, hormone level has a role in the pathogenesis. Hyperestrogenism was reported to be associated with the development of endometrioid cancer and clear cell carcinoma [15]. Okamura $\mathrm{K}$ reported progesterone resistance within endometriosis [11]. This can explain why the use of
DMPA for a long time in our case and the endometriosis also developed into cancer. In addition to that, Endometriosis is associated with a local inflammatory reaction leading to cytokine release. Balkwill and Mantovany offer an description of this link: If genetic damage is the 'match that lights a fire' of cancer, some types of inflammation may provide 'the fuel that feeds the flames [16]. Cytokines within the endometriosis microenvironment, such as IL-1 is associated with increasing the synthesis of prostaglandin E2 (PGE2) which cause angiogenesis, proliferation, and inhibition of apoptosis similar to malignant mechanisms [17].

Table 1 summarize the previous reported cases arising in episiotomy scar together with our case. A total of 4 cases of malignant transformation of episiotomy scar endometriosis have been reported in previous literature.

Table 1 Summary of the carcinoma arising in episiotomy scar

\begin{tabular}{|c|c|c|c|c|}
\hline Author & Year & Histology & Treatment & The follow up \\
\hline Hitti IF [5] & 1990 & Clear cell carcinoma & radiotherapy and chemotherapy & dead at 30 months \\
\hline Todd RW [6] & 2000 & Clear cell carcinoma & radiotherapy and chemotherapy & remission at 6 months \\
\hline Chene G [3] & 2007 & $\begin{array}{l}\text { Serous papillary } \\
\text { Cystadenocarcinoma }\end{array}$ & $\begin{array}{l}\text { Complementary radiotherapy and chemotherapy-Radical and } \\
\text { complete Excision }\end{array}$ & remission at 6 months \\
\hline $\begin{array}{l}\text { Yong-Soon } \\
\text { Kwon [7] }\end{array}$ & 2008 & Clear cell carcinoma & Radical excision & $\begin{array}{l}\text { no evidence of disease to } \\
10 \text { months }\end{array}$ \\
\hline Current report & 2014 & Clear cell carcinoma & radical resection and chemotherapy & $\begin{array}{l}\text { no evidence of disease to } \\
6 \text { months }\end{array}$ \\
\hline
\end{tabular}


Table one list several reports with different treatments of these disease. The radical excision was administrated along with or no adjuvant therapy. Because the tumor size of our patient is big and the histological type was clear cell carcinoma, chemotherapy was administrated in our patient and the recovery of the patient was well till now, but long-term follow-up result of the efficacy of adjuvant therapy is uncertain.

\section{Conclusions}

We report a case of clear cell carcinoma arising from episiotomy scar. There are only three clear cell carcinoma in episiotomy scar reported, no standard treatment established. Accumulation of management data on these rare tumors and Long-term follow-up of such patients is therefore important.

\section{Consent}

Written informed consent was obtained from the patient for publication of this Case report and any accompanying images. A copy of the written consent is available for review by the Editor-in-Chief of this journal.

\section{Competing interests}

The authors declare that they have no competing interests.

\section{Authors' contributions}

AZ and HW designed and conceived of the study and contributed critical reading of the manuscript and editing. LH participated in drafting the manuscript and performed literature review. All authors read and approved the final manuscript.

\section{Acknowledgements}

The authors thank Lei Li for his help with participated in histopathological evaluation.

Received: 3 August 2015 Accepted: 3 January 2016

Published online: 12 January 2016

\section{References}

1. Sampson JA. Endometrial carcinoma of ovary arising in endometrial tissue in that organ. Arch Surg. 1925;10:1-12.

2. Patrelli TS, Berretta R, Gizzo S, Pezzuto A, Franchi L, Lukanovic A, et al. CA 125 serum values in surgically treated endometriosis patients and its relationships with anatomic sites of endometriosis and pregnancy rate. Fertil Steril. 2011;95:393-6.

3. Chene G, Darcha C, Dechelotte P, Mage G, Canis M. Malignant degeneration of perineal endometriosis in episiotomy scar: case report and review of the literature. Int J Gynecol Cancer. 2007;17:709-14.

4. Shalin SC, Haws AL, Carter DG, Zarrin-Khameh N. Clear cell adenocarcinoma arising from endometriosis in abdominal wall cesarean section scar: a case report and review of the literature. J Cutan Pathol. 2012;39:1035-41.

5. Hitti IF, Glasberg SS, Lubicz S. Clear cell carcinoma arising in extraovarian endometriosis: report of three cases and review of the literature. Gynecol Oncol. 1990;39:314-20.

6. Todd RW, Kehoe S, Gearty J. A case of clear cell carcinoma arising in extragonadal endometriosis. Int J Gynecol Cancer. 2000;10:170-2.

7. Kwon Y-S, Nam J-H, Gawon Choi MD. Arising in Endometriosis of a Previous Episiotomy Site. Obstet Gynecol. 2008;112:475-7.

8. Liu H, Leng J, Lang J, Cui Q. Clear cell carcinoma arising from abdominal wall endometriosis: a unique case with bladder and lymph node metastasis. World J Surg Oncol. 2014;12:51.
9. Modesitt SC, Tortolero-Luna G, Robinson JB, Gershenson DM, Wolf JK. Ovarian and extraovarian endometriosis-associated cancer. Obstet Gynecol. 2002;100:788-95.

10. Horton JD, DeZee KJ, Ahnfeldt EP, Wagner M. Abdominal wall endometriosis: a surgeon's perspective and review of 445 cases. Am J Surg. 2008;196:207-12.

11. Peter Svenssen $M$, Jan B. The association between endometriosis and ovarian cancer: A review of histological,genetic and molecular alterations. Gynecol Oncol. 2012:124:164-69.

12. Schmidt D, Ulrich U. Endometriosis-related ovarian tumors. Pathologe. 2014; 35:348-54.

13. Wiegand KC, Shah SP, Al-Agha OM, Zhao Y, Tse K, Zeng T, et al. ARID1A mutations in endometriosis-associated ovarian carcinomas. N Engl J Med. 2010;363:1532-43.

14. Samartzis EP, Noske A, Dedes KJ, Fink D, Imesch P. ARID1A Mutations and PI3K/AKT Pathway Alterations in Endometriosis and EndometriosisAssociated Ovarian Carcinomas. Int J Mol Sci. 2013;14:18824-49.

15. Benoit L, Arnould L, Cheynel N, Diane B, Causeret S, Machado A, et al. Malignant extraovarian endometriosis: A review. EJSO. 2006;32:6-11.

16. Matsuzaki S, Murakami T, Uehara S, Canis M, Sasano H, Okamura K. Expression of estrogen receptor alpha and beta in peritoneal and ovarian endometriosis. Fertil Steril. 2001:75:1198-205.

17. Balkwill F, Montovani A. Inflammation and cancer: back to Virchow? Lancet. 2001:357:539-45.
Submit your next manuscript to BioMed Central and we will help you at every step:

- We accept pre-submission inquiries

- Our selector tool helps you to find the most relevant journal

- We provide round the clock customer support

- Convenient online submission

- Thorough peer review

- Inclusion in PubMed and all major indexing services

- Maximum visibility for your research

Submit your manuscript at www biomedcentral.com/submit
CioMed Central 